\title{
Cannibalism and Gang Involvement in the Cinematic Lives of Asian Gangsters
}

\author{
Richard J. De Caires, Paul T. Lankin and Phillip C. Shon* \\ Faculty of Social Science and Humanities, University of Ontario Institute of Technology, Oshawa, Ontario \\ L1H 7K4, Canada
}

\begin{abstract}
Previous works focusing on Asian organized crime groups have examined the history, structure, function, and the extent of their legal and illegal business enterprises. While credible, such a line of inquiry omits crucial information on the source and reasoning behind membership and affiliation for members in Asian organized crime groups, such as the "Jok-Pok", Triads, and Yakuza. Due to the secretive nature of those organized crime groups, such an omission leaves a major gap in the understanding as to why Asian youths join gangs. This paper examines the prevailing characteristics of membership and affiliation within Asian gangs by analyzing Asian gangsters in Asian (Chinese, Japanese, Korean) cinema. Results indicate that the lure of economic benefits, exposure to gang life from within one's family and lack of opportunities to achieve legitimate goals constitute the three most pervasive themes that define membership within Asian gangs as represented in popular cinema.
\end{abstract}

Keywords: Asian gangs, Asian criminology, desistance, Asian cinema.

\section{INTRODUCTION}

Research has revealed several reasons why individuals join organized crime syndicates and gangs. The findings from this body of research indicate that the determinants of organized crime group/gang membership can be collated into several categories: (1) access to social and economic capital; (2) loyalty and camaraderie; (3) sense of protection; (4) increase in social status; (5) higher income and wages; (6) involvement in drug subculture (i.e., use and trafficking) and; (7) the influence of women and family. Despite such knowledge, a question remains as to why youths in Asia join gangs. That is, little is known about the characteristics and motivation of Asian youths who join gangs. It behooves us to rectify this gap in the literature by exploring the causes of gang membership in Asian countries. This paper attempts to understand why Asian youths join gangs by examining one of the most accessible and pervasive source of exposure to gangs in Asia: films.

The popularity and influence of Hong Kong and Japanese cinema across the world is nothing new (Lu, 1997; Pang, 2002; Rafter, 2006; Schilling, 2003). One of the leading figures in the Hong Kong film industry, John Woo, successfully brought his technique and style to Hollywood, creating several blockbuster hits. While classic Hong Kong films such as Hardboiled (Chang and Kuk, 1992), The Killer (Hark and Woo, 1990), and A Better Tomorrow I, II, III (Hark and Woo, 1986; Lai

\footnotetext{
${ }^{*}$ Address corresponding to this author at the Faculty of Social Science and Humanities, University of Ontario Institute of Technology, Oshawa, Ontario L1H 7K4, Canada; Tel: 905-721-8668 ext. 6516;

E-mail: phillip.shon@uoit.ca/pshon1@yahoo.com
}

and Woo, 1988; Hark and Woo, 1989) are well known by film critics and aficionados alike, much less is known about the recent wave of films in this genre in the three major film producing Asian countries such as China, Japan, and South Korea.

Some scholars have argued that the proliferation of gangster films in countries such as China (Hong Kong), South Korea and Japan has perpetuated fear and facilitated the tolerance for organized crime groups by empowering organized crime groups to thrive on this fear (Chin, 2006; Fickenauer and Chin, 2006). As a result, this fear mongering has allowed crime groups to expand and conduct their activities without disruption (Chu, 2005). Some have also lamented that Asian organized crime groups are exceedingly secretive and difficult to infiltrate, and have had to rely on journalistic accounts and government sources to study gangs in Asia (Zhang and Chin, 2008). Such a perspective, while accurate, overlooks a major source of data about gangs in Asia: films. Consequently, this paper utilizes Asian gangster films as data to discern how public attitudes toward and about gangs may be shaped by the consumption of such films (Zhang and Chin, 2008). Although the present study concentrates on a biased sample of Asian gangster films, the overall findings provide valuable insight into the reasons why adolescents may decide to become gangsters.

For the purposes of this paper, an "organized crime group" is defined as "a structured group of three or more persons existing for a period of time acting in concert with the aim of committing one or more serious crimes or offenses...in order to obtain, directly or indirectly, a financial or other material benefit" 
(Finckenauer and Chin 2006, p. 22). We also use the broad term "Asian gangsters" to refer to organized crime groups and their members who engage in offenses for financial, material, and other gains from the respective countries of China (Hong Kong), Japan, and South Korea.

There are several reasons why an examination of Asian gangsters in cinema is warranted. First, there is an absence of primary research that examines the multitude of intervening factors that compel an individual to join Asian gangs. By utilizing Asian gangster films as data, we explore one potential source of allure for youths to join gangs, as some journalistic accounts have implied (Yin, 2009). Second, there is a paucity of methodological diversity in the gang literature, particularly for Asian gangs. Previous studies have primarily relied on interviews, surveys, and official documents to establish correlational factors associated with gang membership (Im, 2008; Ngai, Cheung, and Ngai, 2007; Tsunokai, 2005; Walker-Barnes and Mason, 2001; Varano, Huebner, and Bynum, 2011). Popular representations of crime and "criminals" are overlooked as a potentially rich source of data about the social and emotional contexts behind why adolescents may join gangs. The use of films constitutes one way that the methodological inertia can be remedied in the gang literature, particularly in the study of Asian gangs (see Lankin and Shon, under review).

Third, assessing the accuracy of the determinants of gang membership in cinema is a topic that has not been addressed by previous research. Determining the veracity of why youths may join gangs in Asia, as represented in popular culture, may allow policymakers and social service professionals to critically intervene in the lives of at-risk youths who may be contemplating joining gangs. As some have noted, the growing number of films about Asian gangsters may promulgate fear amongst the viewing public by sensationalizing their dangerousness and threat to society (Finckenauer and Chin 2006, p. 101).

Studying Asian gangs in the context of Asian films may be important for another reason. Representations of Asians in Western (i.e., Hollywood) films are imbued with racist and sexist undertones, portraying Asian men as asexual creatures, as undesirable objects of female sexual desire, unworthy and incapable of sexual and emotional intimacy by virtue of their race and their race alone (Chen 1996). Or when Asian men have appeared in "masculine" roles, they have still been relegated as nonsexual martial artists who speak with a comedic Asian accent (Park, Gabbadon, and Chernin 2006), or perverts and criminals (Shek 2006). Asian women have usually been cast as the exotic, enigmatic, and sexualized "dragon lady" of the Orient (Said 1978), constructed as the object of European males' desire, as well the desiring beings of European men (Chan 2001, 2007; Kang 1993; Kim, N.Y. 2006). Through a critical examination of Asian gangsters in cinema, we wanted to understand why Asian youths might want to join gangs, as told by the Chinese, Japanese, and Korean-Asian-screenwriters and directors, through films that were intended for those respective audiences. For such reasons, it behooves us to examine why youths join gangs in Asian gangster cinema. Through a critical examination of portrayals of Asian gangsters in cinema, we attempt to contribute to the literature in the following areas: (1) Asian criminology (2) Asian gang studies (3) Asian cinema studies.

\section{BACKGROUND: PRIOR RESEARCH ON GANG MEMBERSHIP}

There are a number of active Asian organized crime groups that are frequently depicted in Asian gangster films, in Asia, as well as internationally (Berry, Curtis, Elan, Hudson, and Kollars, 2003). The most prominent organized crime groups in Asian filmography are the triads (Hong Kong), jok-pok (South Korean), yakuza (Japan), and common Chinese and South Korean street gangs who, as a whole, operate in a variety of illicit and lucrative activities (Chin, 1996; Lo, 2012). Although Asian organized crime groups-and gangs in general-vary in size, flexibility and structure (Jankowski, 1991), they tend to be hierarchically and territorially organized in their illicit activities to ensure stable clientele and profits (Berry et al., 2003; Lo, 2012; Zhang and Chin, 2003). Previous researchers have noted that the risk of gang involvement intensifies as the numbers of determinants increases (Bjerregard, 2010; Coughlin and Venkatesh, 2003; Decker and Curry, 2003; Dukes, Martinez, and Stein, 1997). In the sections that follow, we discuss some of the factors related to gang membership in thematically parsimonious ways.

\section{Economic Benefits of Gang Membership}

There is consensus that entry into and duration of membership into a gang is heavily predicated on the accessibility of legitimate and illegitimate economic and social capital (Bellair and McNulty, 2009; Hagedorn, 
1988; Venkatesh, 2001). Consequently, there is a strong correlation between joining a gang and the limited access to legitimate means of acquiring the culturally prescribed symbols of material success. Economic capital is defined as the availability of any material resources (i.e. financial assets) while social capital is defined as the network of relations forged among actors that lead to favorable outcomes (Pih et al., 2008). Some have even gone as far as to proclaim the ineluctability and inevitability of urban gangs in the face of persistent social inequality and social exclusion in a postindustrial society: "they [gangs] are unlikely to be destroyed as long as ghettos and conditions of extreme poverty continue" (Hagedorn, 2007, p. 311).

The vast majority of illicit activities of Asian gangs that contribute to the acquisition of social and economic capital appear to be derived through lucrative transactions in cross-national narcotics trafficking, counterfeiting, prostitution, arms trafficking, gambling dens, extortion, armed robbery, credit card theft and fraud, loan sharking, money laundering, fraud, contract killings, as well as kidnapping and trading women and minors for Asian entertainment industries (Bolz, 1995; Berry et al., 2003; Chin, 1995; Finckenauer and Chin, 2006; Hughes, Chon, and Ellerman, 2007; Huang, 2006; Kelly, Chin, and Fagan, 1993). The importance of these illicit underground economies is that the crime groups have helped fuel social and economic growth, thereby making them attractive employers of unemployed and underemployed young men (Pih et al. , 2008; Coughlin and Venkatesh, 2003; Zhang and Chin, 2008).

Research has also shown that earnings of gang members have increased due to their participation in the trafficking of illicit goods and services. Furthermore, their participation has led to a reconfiguration of ideology and identities within gangs, as members become entrenched in the logic and ethos of capitalism (Sassen, 2007). In fact, Pih et al. (2010) found that the very essence of Asian gangs has undergone a dramatic transformation, with branches of Asian organized crime groups beginning to refer to themselves as "the company." That is to say, gangs as a whole have transitioned from a loosely organized playgroup turned criminal network to economic machines, the difference between legitimate enterprises and criminal ones being the level of coercion and illegal methods employed to achieve their financial objectives (Pih et al., 2010).

Research also indicates that entry into gang life is also heavily shaped by limited opportunities for social mobility. That is, whether the at-risk youths are stuck in African American ghettos of inner cities in the U.S. (Wacquant, 2007), the barrios of predominantly Latino East Los Angeles (Moore, 2007), or the favelas of Brazil, youths from those communities lack the necessary capital to achieve material success in the larger society (Hagedorn, 2008). They come from low income homes, single-headed households (Esbensen et al., 2001; Lasley, 1992), and limited access to education (Dukes et al., 1997), and as a result, at-risk youths are more likely to be exposed to crime, drugs and violence in their communities (Anderson, 1999; Fox, Lane, and Akers, 2010). Some have even argued that the persistence of such criminogenic communities illustrates the retreat of the state in the face of exigent social need and urgency, leading to the creation and persistence of an identity of resistance and opposition in the disenchanted youths (Hagedorn 1988, 2008). In such hopeless conditions, gangs and membership in them represent an affirmative forward movement in the face of nihilism, a dialectical struggle against social irrelevance and an existential reaction to class domination and oppression (Hagedorn, 2007).

\section{Social Benefits of Gang Membership}

If those who join gangs do so for financially remunerative reasons, then there are also nonfinancial factors that compel youths to join gangs (Howell and Egley, 2005; Howell, 2007; Winfree, Backstrom, and Mays, 1994). Asian gangs-gangs in generalpromote the ideologies of loyalty, inclusion and camaraderie as transcendental values that motivate youths to join gangs (Zhang and Chin, 2003; Pih et al., 2008; Tsunokai, 2005). Decker and Curry (2000) and Huang (2007) posit that gaining status and respect are perhaps two of the most important reasons for joining a gang. This lack of status and respect may be one reason why minority youths are likely to flock to gangs: "institutional racism and pervasive alienated status of Asian and African American youth can lead to gang involvement" (Tsunokai and Kposowa, 2002, p.45). Therefore, the increase in status that gang membership provides may be one reason gang life is attractive because it is one way of resolving conflicts related to identity and culture (Varano, Huebner, and Bynum, 2011).

Asian American youths face an additional risk factor that is unique to minority youths. Caught in between two worlds, the world of their parents and the values of their countries of origin and a value exchange system that encourages selfishness and neurotic individualism 
measured only in terms of acquisition of material wealth, the Asian immigrant youths re-live the tension that sociologists of the early twentieth century noted long ago as a crucial link in the pathway toward delinquency (Shaw and McKay, 1945; see also Bhattacharya, Cleland, and Holland, 1999; Choi, 2007; Mercado, 2000; Thai and Kraemer, 2010; Schwartz et al., 2011; Wallace and Bachman, 1991). That they have been socialized into Confucian values of strict obedience, filial piety, and respect for elders for a period of their lives while being inculcated to embrace independence, individualism, and competition in another has led to a schism between two identities, compelling an escape to gang life-and substance use-as an attractive form of retreatism for Asian immigrant youths (Chao and Aque, 2009; Crane et al., 2005; Hahm, Lahiff, and Guterman, 2003; Hong and Kim, 2011; Judith and Steward, 2000; Tsunokai and Kposowa, 2002).

Another consistent finding is the perception of safety and protection received from alliance and affiliation with gangs (Lo, 2012). Decker and Curry (2000) found that one's membership in a gang provided a form of safeguard and defense from the likelihood of being involved in and victimized by violent acts (Howell and Egley, 2005; Varano, Huebner, and Bynum, 2011). There were also a substantial number of participants (current and former gang members) in their study who sought physical protection, but also wanted to engage in and be a part of violence against others because of that feeling of invincibility created by the gang's protection (Decker and Curry, 2000; Zhang and Chin, 2008). Participants in the study echoed such findings with the following sentiments: (1) "People won't talk about you when you're walking down the street"; (2) "No one in the neighborhood would mess with them; others will think you are hard"; and (3) "[I] feel good about violence" (Decker and Curry, 2000, p.476).

Zhang and Chin (2008) also reiterated the preceding point on a broader scale, stating that Asian gangs residing on the mainland of Taiwan have become very proficient in securing modes of protection from government and law enforcement officials through the use of bribery. As they explain, judicial officers, army officials and/or politicians negotiate with Asian gangs to reap the benefits of the "good life" (i.e. cash, lavish meals, drugs, sex or gifts); in return for a taste of the "good life," corrupt officials provide regulatory favors to gangsters, sometimes providing tip-offs and privileged information to those under police surveillance and investigation; that is, provide protection from the heavy hand of the law (see Huang, 2006; Lo, 2010). Whether it is adolescents seeking protection from street gangs or adult criminals seeking protection from corrupt police and politicians, the logic of gang membership and the social benefits protective umbrellas provide are palpable and consequential.

\section{Gang Membership due to Involvement in a Deviant Social Network}

Extant studies indicate that having friends who participate in criminal activities exerts a significant influence on gang membership (Hill et al., 1999; Tsunokai, 2005). As individuals become more exposed to gang lifestyles, they begin to develop attitudes and behaviors similar to that of the gang members (Lo, 2012; Walker-Barnes and Mason, 2001; Varano, Huebner, and Bynum, 2011). Gang members also had more friends who were also gang members, thereby cultivating their entry into gang life (Decker and Curry, 2000; Howell, 2007; Howell and Egley, 2005). Therefore, an individual's exposure to and personal relationships with gangsters and gangs is a strong predictor of his entry into gang life (Walker-Barnes and Mason, 2001; Winfree et al., 1994).

A study conducted by the Arizona Criminal Justice Commission (2004) found that gang members were more likely to have sold and used drugs and alcohol over the course of their life-time compared to that of nongang members. Such findings conflict with the work of Bjerregaard (2010), who found that membership to gangs had a weak, transient relationship with drug use, drug sales, and subsequent violent behavior. There also appears to be a higher proportion of gang members who partake in the drug subculture at rates higher than nongang members. As a result, there is consensus that gangs and gang members are incidentally involved in the drug subculture, and that drug use and trafficking appear to be nothing more than a manifestation of members' progressively increasing involvement in a multitude of criminal activities (Bjerregaard, 2010; Joe, 1994).

Gang affiliation has been related to a combination of poor relationships (e.g. physical or verbal abuse) between parents and their children, maladaptive parental discipline, lack of consistent family involvement and support, as well as the lack of parental control/monitoring (Tsunokai, 2005; Thlang, 2010). Studies have shown that gang members are more likely to be raised in dysfunctional families than nongang members (Walker-Barnes and Mason, 2001; 
Varano, Huebner, and Bynum, 2011). Thlang's (2010, p. 45) research specifically discussed how a family may provide definitions and attitudes favorable to delinquency, possibly due to parental lack of knowledge or unwillingness to inculcate their children into the adverse consequences of gang involvement. Cultural conflict was also a contributing factor which led to the disharmony between parents and their offspring (Crane et al., 2005). The result of both contributing factors was that cultural dissonance ultimately weakened the child-parent dichotomy, and subsequently increased the presence of problem behavior (Kim and Zane, 2002; Lee et al., 2009; Mosher et al., 2004; Thai, Connell, and Kraemer, 2010; Schwartz et al., 2011), delinquency and gang membership (Hong, 2010). Familial ties within the gang were of import as well when determining gang involvement, for current and former gang members noted that family members within the gang acted as role models for them (Decker and Curry, 2000; Hill et al., 1999; Howell and Egley, 2005; Winfree et al., 1994). It does not help that gangs often organize themselves like extended families, which only increases the lure for alienated youths seeking a sense of belonging (Thlang, 2010).

Despite the vast findings from past research, there are shortcomings in the literature that need to be addressed. First, there is an overreliance on "group processes" and extrinsically framed motivation to explain the individual-level decision making process involved in joining a gang. Individual-level factors are minimized, thereby overlooking existential and moral reasons that may compel a person to join a gang; moreover, reliance on group processes ignores the agency on the part of social actors. Second, while the literature denotes that males join gangs because of the presence of women, and the concomitant benefits associated with the presence of female members (Howell, 2007), such a view unduly reduces the complexity of male-female relationships to one that is simple, and presupposes and perpetuates the sexual objectification of women qua women.

Third, while criminological theory in general provides a fairly straightforward way to reduce involvement in gangs i.e., through formation of prosocial bonds to conventional activities, culture and institutions (Laub and Sampson, 2003), increasing attachment to family (Ngai et al., 2007), or improving the economic opportunities of marginal youths (Hagedorn, 1988), the applicability of American criminological theories remain tenuous, at best, in relation to Asian contexts. While Western societies value individualism and competition, Asian societies differ from their counterparts in that collectivism and group cohesion are codified as culturally ubiquitous values (Kim, Atkinson, and Yang, 1999; Hendershot et al., 2005). Thus, prosocial values that western criminology promote are already interwoven into the moral fabric of social life in countries such as China, Japan, and Korea. Such cultural values are vestiges of a Confucian value system that has-and continues to-defined the worldview of Far East nations.

Fourth, while the actual reasons adolescents join gangs may be valid and have been solicited in their own right, such an approach to the question of motivation misses two facets of additional social scientific research: (1): how others may perceive why adolescents join gangs (2) how that perception is disseminated to the viewing public who may be exposed to such narratives of motivation without access to the truth as articulated by the subjects themselves.

The use of popular films allows us to delve into the aforementioned gaps in the literature in the following ways. Individual level factors that may push a person to join gangs can be contextualized in the cultural, social, and political context of that particular society due to the film's historicity (Lankin and Shon, under review). Therefore, group processes and individual level factors can be examined concurrently. An exploration of why youths join gangs may illuminate other findings related to the emotional and organizational contours of gang life. The use of films may yield findings that cannot be captured through conventional social scientific methods (e.g., surveys, interviews). That is why films, as historical and cultural documents, have the potential to illuminate the logic of social behavior, as represented in the cinematic lives of Asian gangsters.

\section{DATA AND METHODS}

All of the films viewed for this project were foreign language films that were produced in the respective countries of China (Hong Kong), Japan, and Korea; the films could most aptly be categorized as those in the gangster genre. One of the authors is an Asian gangster film aficionado who happens to possess hundreds of gangster films in his personal collection. The films were viewed with the aid of English subtitles (for a complete list of films used for this paper, see appendix for filmography). While there are literally hundreds of films in this genre from all three countries, 
only thirteen films were selected for this project. That is, out of the hundreds of poorly written, directed, and acted films, only those films that were most plausible, realistic and authentic representations of triads, yakuza, and jok-pok were selected. The thirteen films used for this project thus represent a biased sample rather than a random sample of gangster films.

Asian gangster films in particular are a genre that is quite limited in popularity and viewership. Consequently, little is understood by outsiders concerning the categories of Asian gangster films outside of their respective countries, much less to the wider, international, English-speaking viewers. With the predominance of western culture (i.e., Hollywood) in cinematography, authentic Asian gangster films are susceptible to being ignored or disregarded by nonAsian viewers as they may encounter difficulties in understanding and relating to the characters in the film due to cultural differences and nuances in language. Despite this limitation, several of the films in this research study have received international acclaim and recognition and are ranked as some of the foremost gangster films ever produced. Each of the authors viewed and coded the films, with particular attention being paid to determinants of gang membership in the crime groups, as well as the characteristics and features of violent acts.

The initial viewing of the films took place with no preconceptualized categories or themes. That is, consistent with the principle of qualitative inquiry, no predefined areas of research or theoretical issues were identified in advance. After the initial viewing was nearly completed, however, it became apparent that certain themes were emerging from the primary material. One recurring theme was the reasons why Asian youths joined gangs. Using the principle of grounded theory and analytic induction (Strauss, 1987) the reasons for joining were then collated and classified into thematically parsimonious analytical categories during the coding process (Emerson et al., 1995).

The limitations associated with this use of data and method of analysis are two-fold. First, while there were a plethora of films watched in succession, only thirteen were selected, viewed, and included in this project. The films thus reflect the biased selection of one aficionado rather than an objective measure of film popularity or success as perhaps measured by number of accolades received or ticket sales. Second, it would have been ideal to have included a larger number of films into this study. However, the artistic value of most of the films in one of the author's personal collection was shoddy if diplomatically stated and offensive if realistically stated. Third, the choice of these films is wholly oriented towards the Asian culture and life in the East. None of the abovementioned films details the membership characteristics and presence of Asian gangs in the West (i.e. California), which some research covers extensively. This exclusion was purposely carried out.

As noted in another work (Lankin and Shon, under review), the way Asians in general are portrayed in Western cinema-and media-has been one of gross caricature. The men tend to be represented as inept fools, perverts and sexual deviants, or thickly-accented asexual characters while women tend to be represented as objects of sexual desire for European American men (Chan, 2007). Asian men and women who appear in gangster films still have not escaped such racist stereotypes. For instance, in the Hollywood film about the yakuza in Los Angeles entitled Brother (Thomas and Mori, 2001), a rogue yakuza member arrives in town to visit his brother; during his stay, he finds that his half brother is being hunted by the local Italian mafia. A war ensues, and in the final scene, the Italian mafia magically slaughters the Japanese yakuza. In another highly regarded Hollywood movie about the yakuza called The Yakuza (Pollack, 1975) the principal character (Kilmer) is called on to settle a feud. The subtext of both films is clear: yellow-skinned people cannot defeat European Americans even in the underworld; moreover, a European American male appears at the savior and hero of the film. Such a subtle message is not that different from ones that depict Asians as inferior, sly, and obsequious "Other." This is the reason why movies about Asian gangsters in the west were excluded. In the following sections, the significant themes that emerged from the qualitative analysis of Asian gangster films are presented and discussed.

\section{Eking Out a Living: The Cannibalistic Path of Upward Striving}

Asian gangsters and the American television family Jeffersons have much in common: they are all trying to "move on up" to acquire a "piece of the pie." This theme permeates across the gangster films from the respective three countries, and reinforces existing scholarship on why individuals join gangs (e.g., Pih et al., 2010). Moreover, upward striving suffuses the relationships of low-level gangsters to middle-level gangsters (dai-los, hyoung-nims, and oyabuns), and the preceding two to the chieftains of a crime group. 
The subtext of this motif becomes apparent in that the accumulation of wealth, power, and territory account for the allure of becoming a gangster, as it is represented in the films. Those who have money and status simply strive to acquire more while those who don't fade away and become irrelevant; various characters throughout the films fight against this social irrelevance and obsolescence.

This desperate upward striving is evident in the character Byoung-Doo, the tragic hero of the South Korean film Dirty Carnival (Cha, Sung and Kim, 2006). Byoung-Doo is looking to make money, not for himself, but for his family; and he has two of them: biological and social. He needs to make money to pay for his mother's medical expenses and to pay for his sister's tuition and school-related expenses. When his mother laments how she will pay the necessary medical costs, Byung-Doo tells his mother, "Don't worry Mom, l'll take care of it." He is the man of the house; he is the elder brother (hyoung nim) to his crew. He is simply trying to provide for his family, and enact the role of a filial son and a brother; and by fulfilling his filial duties, he becomes a good gang leader as well.

As a hyoung nim, he is struggling to feed another family as well: his underlings. Rather than celebrating their gathering in a stylish bar with hostesses, they are relegated to grilling pork bellies on a fry pan on a newspaper-covered floor and throwing down shots of soju (Korean wine). The scene is pathetic and shares an eerie resemblance to his home life: they are all down and out; they sit on the floor, eat on the floor, and relate their woes to one another on the floor. ByoungDoo and his crew occupy the bottom rung of his crime group; his crew comes from the bottom of society; their station in life and within the gang is metaphorically symbolized in this scene. The crew's compensation for the last few jobs have not been remunerative; they are literally living hand-to-mouth; he appeals to his boss for more payment, but he is rebuffed as being too ambitious. When an opportunity arises to kill a corrupt prosecutor for a benefactor, he willingly takes on the dangerous mission in his upward climb. Byoung-Doo will ascend his way to economic prosperity by burying a corrupt public official.

This upward striving is coupled with an internal moral dilemma in Byoung-Doo. He is exhorted by his mother and girlfriend-to-be to abandon the wanton and dangerous life of a thug; his love interest compels him to seriously ponder quitting the gang; however, he is also trapped as he has to consider his other family-his brothers and underlings in the gang-and doing so entails taking risks, even at the cost of placing his standing in the gang in jeopardy. The chieftain (whejang nim), who is Byoung-Doo's benefactor, too, is caught in a dilemma. He is repeatedly harassed by a corrupt prosecutor named Mr. Park for illicit favors; and he can't refuse him, for Mr. Park has the capacity to unleash the force of the police and courts on him. The whe-jang has no choice but to arrange to kill Prosecutor Park. His promise to Byoung-Doo is that when his newly constructed apartment complex is completed, Byoung-Doo and his subordinates will reap a handsome reward for their help; the whe-jang will even throw in a sizeable apartment for Byoung-Doo and his mother and sister. But in order for the whe-jang to become a legitimate businessman, he has to completely rid his ties to the underworld and become "clean." To cleanse himself in order to become a legitimate part of society, he hires Byoung-Doo to kill the corrupt prosecutor.

The upward striving of the principal characters in the film are evident: Byoung-Doo wants economic security for himself and his family; whe-jang wants to become a legitimate businessman and integrate into the larger society through his businesses; ByoungDoo's childhood best friend (Min-Ho) wants to exploit the life of his friend and direct a realistic film about the life of a gangster to get ahead. In the final scene, Byoung-Doo's subordinate (Jong-Su) kills him in order to become a hyoung-nim himself. The moral of the story is thoroughly cannibalistic: everyone feeds on one another for the sake of upward mobility: get yours orto paraphrase a well-known gangsta rap artist- "get got."

Infernal Affairs (1, 2, 3) tells the story of two principal characters who are caught in a moral quagmire: a cop who is planted as a mole inside a triad, and a triad gangster who is planted inside the police force as a mole. Although remade as an Oscarwinning Hollywood film, the remake does injustice to the complex plots and subplots embedded in the original Hong Kong classic.

The Ngai family has been a fixture in Tsim Tsu Ha since Uncle Kwon began his illegal trade as a bookie; the family has since amassed a fortune and controls all of the illegal action in Hong Kong: the five bosses within the HK territories must pay monthly tributes to the Ngai family. Infernal Affairs 2 begins with the assassination of Uncle Kwon by the young Inspector Lau, a gang mole. The youngest son takes over the 
family business. Yan, the undercover police agent, gathers evidence for a case against the Ngai family.

In the Infernal Affairs trilogy, the upward striving is signified by nostalgia for normalcy. The Ngai family plans to run for office and become legitimate in HK society. They have bribed the necessary officials, but one person stands in the way: Superintendent Wong who is persistent in pursuing the Ngai family for racketeering and murder; he impedes the Ngai family's attempt at "coming out of the shadows." In fact, the entire cast of characters is trying to become legitimate: Yan wants to leave his role as an undercover agent playing the role of a gangster and assume regular police duties; Inspector Lau too wants to leave his job as a gang mole and become a regular cop for the sake of his wife. The Ngai family desires to leave the underworld and become legitimate in the eyes of the public. The only true gangsters in the film are Hon Sam, a pudgy triad boss who is keen on eating and whoring, and Superintendent Wong who orders the killing of Uncle Kwon while screwing Hon Sam's wife. A veteran cop and a ruthless gang boss are not that different. The subtext of the film is that leading inauthentic lives produces anxiety and is replete with danger; eventually, inauthentic lives become exposed. The result is an ignominious death. Infernal Affairs too tells the story of the cannibalistic process of upward striving.

In this sense the Asian gangster films accurately depict the trajectory of actual gangs in an important way: the process of institutionalization (Hagedorn, 2009). Institutionalization has been described as the final stage in the maturation of gangs as they "establish a symbiotic relationship with the social milieu in which they operate. Members transform their images from the 'stereotypical gangster' to legitimate members of the society and become involved in commercial activities" (Chin, 1995, p. 57). Asian gangster films manifest this upward movement toward legitimacy through the desire and pursuit of emotional normalcy in the aspiration of their characters.

The economic security of gangster life may be one reason why adolescents in particular join gangs; such a conjecture can be supported from the content of the films. However, when the movement of the gangs as an organization is examined the economic attraction can be extrapolated more broadly to one of seeking legitimacy and normalcy through a process of institutionalization. Whether the films and characters are set in Hong Kong or Seoul, all of the characters are trying to get ahead; trying to make a living; be good to one's followers, family, and boss. For youths who come from broken homes, gangster life provides an illusion of wealth, belonging, status, and having "made it" as the cinematic gangsters don stylish clothes and drive expensive cars (Winfree et al., 1994). Such images are patently obvious to viewers. However, the cinematic lives of Asian gangsters, when analyzed textually, are quite different. The soldiers are beholden to their big brothers; the big brothers are beholden to their big big brothers (dai-dai Lo, keun hyoung nim), who have one foot in the legitimate world and the other in the filth and blood of the underworld; and they too must answer to corrupt police, prosecutors, judges, and public officials; elected officials themselves are dependent on the cooperation of low-level gangsters to not disrupt lives of their constituents.

For gangsters, the attempt at institutionalization provides a semi-permanent face of stability in an otherwise chaotic world of Shakespearean betrayal, paranoia, and death. On an individual level, it is precisely this unpalatable aspect of gang life that leads to the desire for normalcy. The Asian gangster films also provide a fictionalized look at the inner working of organizations and the characters within them who must live the reality of the gang's upward striving. As shown here, the films depict a world of cannibalistic frenzy as one person-group-who is beholden to another consumes others in order to get ahead. Economic benefits of joining a gang describe an individual level motivation; when applied at an organizational-level, the desire for economic success translates to economic security and legitimacy through institutionalization. The path toward becoming legitimate, as represented in films, is deliciously cannibalistic.

\section{Cannibalistic Loyalty}

Loyalty and camaraderie have been touted as emotional reasons why adolescents join gangs (Decker and Curry, 2000; Varano et al., 2011). To an extent, such observations are supported in the films. Cinematic gangsters are loyal to their friends, and will fight on their behalf or in their defense when the situation demands it. In the Japanese gangster film Yakuza Demon, unyielding loyalty is demonstrated between Muto and Seiji (Naito and Miike, 2003). When Muto decides to assassinate the Boss of the Tendo Yakuza Family, Seiji becomes aware that his leader could face at least fifteen years in prison, and is especially cognizant of how serious and dangerous an act like this would be. Seiji offers to orchestrate the assassination 
for Muto, allow him to take all the money that would come from this gang hit, and Seiji himself would take the rap and go to jail for fifteen years. Likewise, when Muto rejects Seiji's offer, Seiji's loyalty towards his leader becomes evident again. Seiji defies his leader's advice, and plans the murder of the upper echelon bosses of their rival gang (Tendo Family). In doing so, he intentionally places a call to law enforcement officials, and indicts his friend and leader Muto, as a way of shielding him from the violence to come.

Towards the end of Yakuza Demon, viewers witness two profound scenes which poignantly represent the theme of loyalty. When Seiji discovers that Muto was killed in prison, for being suspected of orchestrating the assassination of the Tendo bosses, Seiji makes a trip to the courthouse where Muto's killer is about to stand trial. He then makes the decision to kill the man responsible for murdering Muto. Seiji's last act of loyalty is an act of revenge on behalf of Muto. When the Tendo Family learns of Seiji's actions, they too decide to take revenge for their loss. As gunfire blazes towards Seiji and Sachie, Seiji, in the ultimate act of honor and loyalty, jumps in front of Sachie, acting as a shield from the hail of bullets coming from the weapons of the Tendo Family.

As the film progresses, we see the relationship between Muto and Seiji mature, and with it comes an increasing level of dedication and loyalty towards one another. Many of the thematic representations of loyalty seen in this film corroborate prior research which indicates that Asian gangs' emphasis on ideologies of loyalty, inclusion and camaraderie as prominent characteristics motivating membership (Zhang and Chin, 2003; Hagedorn, 2009; Pih et al., 2008). For youths who have grown up in homes impoverished of feelings of love and belonging, the sense of commitment and loyalty that gangs provide serve as a powerful emotional allure of entering the life of an Asian gangster.

Camaraderie and loyalty appear to be attractive transcendental values of gangster life-on the surface. Again, to those who may have grown up in broken and loveless homes, the prospect of intimacy with one's peers is an attractive incentive for joining a gang, in addition to the remunerative aspects of the lifestyle. However, viewers are treated to how loyalty and brotherhood within the gang's ranks are ultimately held to be a false ideology-ideology that is destroyed by a principle antithetical to its purported aim: self-interest. This illusory character of loyalty and friendship is reflected in one of the classic Korean gangster films, Friend.

In the film Friend, four individuals with four very different backgrounds mature into adulthood (Seok, 2001). Joon-Seok, Dong-Su, Jung-Ho and Sang-Taek are the central characters whose lives become immersed in the gang subculture. Joon-Seok's father was a mob boss, and when he dies, Joon-Seuk, who had been exposed to the gang life during his childhood, inherits his deceased father's role. Meanwhile, Dong$\mathrm{Su}$, who is the rival boss of another gang, becomes embroiled in a war against Joon-Seok and his gang. However, throughout the film loyalty to childhood friendship and memories appear to militate against violence against one another.

Although the classic film is entitled Friend, what the viewers are treated to is the tragic irony and contradiction that is embedded in the term, for JoonSeok orders the hit on his long-time best friend-and a rival in an opposing gang-Dong-Su. Dong-Su in turn is betrayed by his trusted lieutenant, and is subsequently stabbed to death in the street. Like a fish out of water, Dong-Su dies an ignominious death in the gutter, alone, cold, and convulsing uncontrollably as life seeps out of him. Joon-Seok is also shown in the final scene, surrounded by two prison guards as they accompany him to the gallows to be executed for his crime. The concept of loyalty in a gang is shown for what it is: a useless and dead value that is best left on the street, to be swept up by the falling rain and into the gutters, or left on the gallows. The subtext is unmistakable: there is no such thing as loyalty in gangster life. Such subtle messages, however, are apt to be missed if viewers concentrate on the appearance of loyalty.

\section{Gangster by Default: The Formation of Gang Identity as a Function of Repressive Structures}

If Asian gangster films provide an implicit rationale for the reasons why individuals join gangs-eke out a living, upward mobility, camaraderie-the role of the government and authority structures that may wittingly or unwittingly produce gangs are not excluded from the subtle messages embedded in the films. Such scathing criticisms of the state, structures of inequality, and oppression are sometimes tacitly but and profoundly conveyed by the way the filmmakers cultivate ironic symbolism. Consistent with the extant research which posits that gangs are a reaction formation to the racial, ethnic, and economic oppression suffered at the hands 
of the ruling capitalist class and agents of social control (e.g., Hagedorn, 2008), Asian gangster films also reflect that trend in the gang literature.

Attack in the Gas Station follows a quartet of petty Korean gangsters who whimsically decide to rob a gas station-for a second time (Kim and Lee, 1999). During the course of the robbery they commit acts that can only be described as wacky and odd. One theme that marks the point of the film is a clear absence of any particular overriding reason for joining the gang or persisting in it, perhaps other than the avoidance of boredom. Viewers later discover, however, that these youths are committing these so-called capricious and bizarre acts as a reaction to the injustices they perceive society has perpetrated against them, and the opportunities that they have been denied because of their station in life.

Viewers are shown that the gangsters at one time aspired to be a baseball player, a rock musician, a painter, and a law enforcement officer; throughout a series of flashback vignettes, viewers are treated to how their lack of access to legitimate goals and methods of achieving them results in a life of delinquency. Attack in the Gas Station thus encapsulates how the lack of opportunity to achieve legitimate goals can create a subjective experience of anger and resentment towards society and the authority figures who have ignored and stigmatized them (Kent, 1998). Robbing a gas station then functions as a semiotic accusation of the state, a symbolic act of revenge against the state for its failure to nurture the youth from the pitfalls of delinquency, for its failure to cultivate a feeling of social hope and legitimate aspirations of ambitious young men (Im, 2008; Greene and Pranis, 2007; Mouttapa et al., 2010). From a state and social structure that ignores the aspirations of young men, joining a gang and engaging in petty and serious mischief, then, is one way of affirming one's place in an unjust world (Hagedorn, 2008, 2009).

The unjust world that the film critiques are the structures of Korean society: a society that worships material wealth, where bribery is a customary practice even in the education system; the absence of a banking system that caters to the small businesses and creative artists, who then must rely on organized crime groups to secure high-interest loans; a society that privileges academic success over artistic expression; and an overly stern parenting style imbued with Confucian value system that elevates authority over the truth. Attack in the Gas Station signifies what the gang members' lives would have become in an ideal world, a world that is not marked by such rigid belief and value systems: a gangster who would have become a professional baseball player; a gangster who would have become a law-enforcing security guard; a gangster who would have become a successful musician; a gangster who would have become a commercial painter. Viewers are shown this alternative world at the very end of the film, along with the credits.

\section{DISCUSSION}

This paper has selectively sampled and used thirteen films that could putatively be classified as Asian gangster films. The films used as data for this study originated out of Hong Kong, Japan, and South Korea. A cinematic analysis of the films revealed that there were several cross-cultural themes about gang life that could be discerned, despite their origins from three distinct countries, with their unique history and language.

First, why individuals join gangs in Asia is not all that different from what gang researchers in the West have noted. Asian youths join for reasons that are already poignantly known: for a sense of belonging and camaraderie and for upward mobility (Decker and Curry, 2000; Hill et al., 1999; Howell, 2007; Howell and Egley, 2005; Ngai and Ngai, 2007; Pih et al., 2008; Winfree et al., 1994). Just as gangs across the world are populated by lower class youths who are economically marginalized (Fox et al., 2010; Dukes et al., 1997) and face hopelessness (Hagedorn, 1988), our findings indicate that the backgrounds of cinematic gangsters too originate from such an absence. As such, the desire for upward mobility was a salient theme throughout all of the sampled films. Should the sample be widened, it is likely that the backgrounds of the characters would not vary that much.

Second, a careful analysis of the films reveals that the professed attractions of gang life are rife with contradictions and ironies that are apt to be missed without careful textual analysis. As already mentioned, enlisting in a gang leads to an increase in status and wealth; our analysis supports such a view. However, if the plot, characters, and their overall movement are analyzed elliptically, then a much more unpalatable picture emerges. That picture, we have contended, is cannibalistic, for despite the upward trajectory in the social status of the characters and gangs as a whole, the cost of that ascendancy is paid with the flesh and 
blood of gangsters at all levels. Low-level gangsters consume their peers to become middle-level managers, who in turn, victimize their peers and superordinates to become bosses. This intra- and intergang feeding frenzy extends into the value system that purportedly functions as a transcendental core value. Although one of the Korean gangsters articulates that "loyalty is life," such a pithy aphorism contains no truth value in the cinematic lives of Asian gangsters, for our analysis indicates that loyalty means nothing more than taking what belongs to others before they snatch it away. Such a view of loyalty contravenes one of the principal rationales gang members cite as a reason for joining a gang (Zhang and Chin, 2003).

If indeed movies about triads, yakuza, and jok-pok serve as sources of information about gang life, that the depiction of gangsters in cinema glamorizes them (Yin, 2009), then counteracting such misconceptions too is a readily achievable task, for the flashy lifestyle and moral values that youth cite as reasons for joining can be shown to be what they really are: illusions. Having actual gangsters who are incarcerated and having them relate the actual at-risk youths about what loyalty is really like within gangs may be one intervention tactic that may function as turning points in their lives-tactically crafted redemption scripts necessary to enact behavioral and psychological change (Maruna, 2001). Rather than trying to scare the youths into deterrence and desistance from juvenile delinquency and gang membership, the truth about what gang life is like-i.e., death, prison-told by authentic characters who have paid the ultimate price-denial of freedom-just may effectuate a real change in their life scripts than through the stories told through the lives of cinematic gangsters. The films could serve as impetus to get the dialogue started between youths and the appropriate criminal justice authorities. In that sense, the fictional stories may hold potential to be realistic tools of moral change for at-risk youths.

Finally, the films provide a lesson for criminology as an academic discipline. One of the main criticisms that has been made of the current state of gang research is that the literature conflates theories of delinquency with theories of gang formation (Hagedorn, 1988). The latter necessarily entails an analysis of the political economy along with the social structures that facilitate the rise of gangs rather than individual-level risk and protective factors. As argued in this paper, Attack in the Gas Station provides a paradigmatic example of how delinquency, gang formation, and the repressive authority structures coalesce together to produce alienated youths who become attracted to gang life. In Attack in the Gas Station, the youths become wayward when their creative and logical outlets of expression are repressed and denied by rigid parents, a corrupt education system, an inflexible economic system, and an authoritarian teacher. The moral of the film is opaquely hidden in the credits, as viewers are reluctantly shown what might have been: bad structures that produce bad kids.

Perhaps the director had in mind the state of politics in South Korea. Scholars have shown that Korean cinema was heavily censored by repressive dictatorial regimes well into the 1990s (Park, 2002). Especially under the totalitarian regimes of Park and Chun, films that criticized the government in any way or offended the moral sensibility of the conservative public were censored (Lee, 1980; Suh, 1982). Only after the directors were released from the restrictions implemented by the heavy hand of censorship did international blockbusters such as JSA (Lee and Park, 2000) and Shiri (Kang, Byeon, and Lee, 1999), along with internationally renowned directors like Park ChanWook and Kim Gi-Duk, emerge in the Korean cinema scene. The message is implicit but clear: bad political systems produce bad films.

It is that critique of the state of gang researchalong with a scathing criticism of the repressive South Korean government-that is echoed in the cinematic lives of the four Korean gangsters in Attack in the Gas Station. Gangs are a reaction to the conditions of hopelessness, economic stagnation, and repressive authority (Hagedorn, 2008). But if gangsters are hopeless youths who eke out a living on the street, then what is the appropriate nominative category for corrupt police, judges, prosecutors, and politicians who operate their protective umbrellas in the way streetlevel gangsters levy street taxes on ordinary businesses (see Esbensen et al., 2001)? Hagedorn (2009) argues that dirty politicians and gangsters are not that different. Such an assertion ought to be very disconcerting for criminology as a discipline for no other academic discipline's research agenda and object of scholarly inquiry (i.e., murder, robbery, crime) are codified in and through the law (Reiman, 2008). But that is exactly where the contradiction lies, for the very categories are constructed by those who are charged with creating and enforcing the law (Maclean and Milovanovic, 1997; Quinney, 1977). The police and corrupt politicians would then have to talk gangs and 
gangsters into existence to suit their needs (Meehan, 2000).

Perhaps that is why a criminology that is based on principles of positivism and empiricism face an impasse in explaining crime and deviance (Henry and Milovanovic, 1996). There has to be a way to move beyond a criminology based on the logic of measurement to one that examines how the ruling class perpetuates itself and how those hopeless youths find ways to resist in quotidian ways (Hagedorn, 2008); criminology as a discipline has to move beyond tests of significance and seek templates of interpretation to examine how behavior becomes criminalized-that is, a criminology of realism and transgression (Young, 1997, 2007). Just as international blockbuster hits emerge out of South Korea after censorship and oppression are lifted, it just may be oppressive structures of a capitalist market system which worships competition, profit, and dividend which may exert an ecological force in the production and sustenance of gangs (see Currie, 1997; Hagedorn, 2008; Sassen, 2007). That is a lesson that criminologists can learn from the cinematic lives of Asian gangsters.

\section{CONCLUSION}

There are three limitations to be considered for future studies of this kind. Firstly, the sample size for the movies chosen (thirteen) was too small. In an analysis of this kind, it would have been much more comprehensive in scope to analyze a larger number of films. However given the issue of timing as consideration, as well as the repetition of themes dictating gang membership in the films chosen for this analysis, future research should consider the use of more films of a greater cinematic variety.

The second limitation of this study is the lack of representation the films chosen for this analysis has for the presence of Asian gangs in the United States, such as California. The films chosen for the purposes of this study relied solely on films portraying Asian gangs in the East (i.e. China, Hong Kong, etc.). Previous research has solidified the establishment of Asian gangs in the West, yet none of the films used demonstrated this. Despite the fact this was an intentional approach taken, future research should look into performing a cross-cultural comparative analysis, looking at both Asian cinema and Hollywood cinema, in order to extricate the similarities and differences both cinematic forums take to portraying Asian gangsters in their films, further validating the research findings.
A third and final limitation of this study is the danger posed from using these films as a point of critique. When filmmakers make their movies, presumably they do their research on the subject area in order to gain an understanding of the subject matter. Nevertheless, elements will be exaggerated and sensationalized in order to make the film more exciting and appealing to viewers. Thus, it can detract from social science merit they may have, as the truth about these gangs may be combined with exaggerated perceptions, thus taking away from the accurateness of the portrayal. Future research should consider this point and implement measures to avoid this issue.

\section{FILMOGRAPHY}

Ahn, S.H. (Producer), and Song, H.S. (Director). (2001). Failan [Motion Picture]. South Korea: Cine Qua Non Films

Cha, S.J., and Kim, M.H. (Producer). (2006). Cruel Winter Blues [Motion Picture]. South Korea: Sidus Pictures.

Cha, S.J., Sung, K.J., and Kim, M.H. (Producer). (2006). A Dirty Carnival [Motion Picture]. South Korea: Sidus Pictures.

Chan, P. (Producer), and Yee, T.S. (Director). (2007). Protégé [Motion Picture]. Hong Kong: Golden Village Pictures.

Fong, H., and Yee, T.S. (2009). Overheard [Motion Picture]. Hong Kong: Bona Entertainment.

Fukasaku, K. (Director). (1972). Street Mobster [Motion Picture]. Japan: Toei Company.

Kang, J.G. (Director), and Byeon, M. R. and Lee, K. H. (Producers). (1999). Shiri. [Motion Picture]. Korea: Destination Films.

Kim, M.H., and Lee, K.S. (1999). Attack in the Gas Station [Motion Picture]. South Korea : Fun and Happiness.

Lau, W.K. (Producer), and Lau, W.K. and Mak, A. (Directors). (2002). Infernal Affairs [Motion Picture]. Hong Kong: Media Asia Distribution

Lau, W.K. (Producer), and Lau, W.K. and Mak, A. (Directors). (2003). Infernal Affairs 2 [Motion Picture]. Hong Kong: Media Asia Distribution.

Lau, W.K. (Producer), and Lau, W.K. and Mak, A. (Directors). (2003). Infernal Affairs 3 [Motion Picture]. Hong Kong: Media Asia Distribution.

Law, D. and To J. (Producers), and To, J. (Director). (2005). Election [Motion Picture]. Hong Kong: China Star Entertainment Group.

Mori, M., Nabeshima T. and Yoshida T. (Producers), and Kitano, T. (Director). (2003). Sonatine [Motion Picture]. Japan: Shouchiku Company.

Naitô, S. (Producer), and Miike, T. (Director). (2003). Yakuza Demon [Motion Picture]. Japan Shochiku Eiga.

Lee, E. (Producer), and Park, C.W. (Director). (2000). JSA. [Motion Picture]. Korea: CJ Entertainment.

Pollack, S. (Producer and Director). (1975). The Yakuza. Burbank, CA: Warner Brothers.

Seok, M.H. (Producer), and Kwak, K.T. (Director). (2001). Friend [Motion Picture]. South Korea: Korea Pictures.

Shundo, K. and Yoshida T. (Producers), and Funkasaku, K. (Director). (1971). Sympathy for the Underdog [Motion Picture]. Japan: Toei Company

Thomas, J. and Mori, M. (Producers), and Kitano, T. (Director). (2001). Brother [Motion Picture]. Culver City, CA: Sony Pictures. 
Hark, T. (Producer) and Woo, J. (Director). (1989). The Killer [Motion Picture]. Hong Kong: Hong Kong Legends.

Hark, T. (Producer) and Woo, J. (Director). (1986). A Better Tomorrow [Motion Picture]. Troy, Ml: Anchor Bay Entertainment.

Lai, A. (Producer) and Woo, J. (Director). (1988). A Better Tomorrow II [Motion Picture]. Troy, MI: Anchor Bay Entertainment.

Hark, T. (Producer). (Producer), and Woo, J. (Director). (1989). A Better Tomorrow III [Motion Picture]. Troy, MI: Anchor Bay Entertainment.

Chang, T., and Kuk, L. (Producers), and Woo, J. (Director). (1992). Hardboiled [Motion Picture]. Hong Kong: Golden Princess Film.

\section{REFERENCES}

Ahn, S.H. (Producer), and Song, H.S. (Director). (2001). Failan [Motion Picture]. South Korea: Cine Qua Non Films.

Anderson, Elijah. 1999. Code of the Street: Decency, Violence, and the Moral Life of the Inner City. New York: W.W. Norton.

Arizona Criminal Justice Commission (2004). A study of the 2002 Arizona Youth Survey: Gang Membership Among Youth. (www.azcjc.gov/ACJC./Youth_Gangs_in_Arizona_Report090 92004.pdf)

Bellair, P., and McNulty, T. (2009). Gang membership, drug selling, and violence in neighborhood context. Justice Quarterly, 26(4), 644-669.

Berry, L.B., Curtis E. G., Elan S. L., Hudson R. A., and Kollars N. A. (2003). Transnational activities of Chinese crime organizations. Trends in Organized Crime, 7(3), 19-59.

Bhattacharya, G., Cleland, C., and Holland, S. (1999). Peer networks, parental attributes, and drug use among AsianIndian adolescents born in the United States. Journal of Immigrant Health, 1(3), 145-154.

Bjerregaard, B. (2010). Gang membership and drug involvement: Untangling the complex relationship. Crime and Delinquency, 56(1), $3-34$.

Bolz, J. (1995). Chinese organized crime and illegal alien trafficking: Humans as a commodity. Asian Affairs, 22(3), 147-158.

Cha, S.J., and Kim, M.H. (Producer). (2006). Cruel Winter Blues [Motion Picture]. South Korea: Sidus Pictures.

Cha, S.J., Sung, K.J., and Kim, M.H. (Producer). (2006). A Dirty Carnival [Motion Picture]. South Korea: Sidus Pictures.

Chan, A.B. (2001). Yellowface: The Racial Branding of the Chinese in American Theatre and Media. Asian Profile, 29(2), 161177.

Chan, Anthony B. 2007. Perpetually Cool: The Many Lives of Anna May Wong (1905-1961). New York: Scarecrow Press.

Chan, P. (Producer), and Yee, T.S. (Director). (2007). Protégé [Motion Picture]. Hong Kong: Golden Village Pictures.

Chao, R., and Aque, C. (2009). Interpretations of parental control by Asian immigrant and European American youth. Journal of Family Psychology, 23(3), 342-354.

Chen, C.H. (1996). Feminization of Asian (American) men in the U.S. mass media: An analysis of The Ballad of Little Jo. Journal of Communication Inquiry, 20(2), 57-71.

Chin, K. (1995). Triad societies in Hong Kong. Transnational Organized Crime, 1, 47-64.

Choi, Y. (2007). Academic achievement and problem behavior among Asian Pacific Islander American adolescents. Journal of Youth Adolescence, 36(4), 403-415.

Chu, Y.K. (2005). Hong Kong Triads after 1997. Trends in Organized Crime, 8(3), 5-12.

Coughlin, B., andVenkatesh, S. (2003). The urban street gang after 1970. Annual Review of Sociology, 29, $41-64$.
Crane, D., Ngai, S., Larson, J., and McArthur, H. (2005). The influence of family functioning and parent-adolescent acculturation on North American Chinese adolescent outcomes. Family Relations, 54(3), 400-410.

Currie, E. (1997). Market society and social disorder. Pp. 37-42 in Thinking Critically About Crime. Edited by B. MacLean and D. Milovanovic. Richmond, BC: Collective Press.

Decker, S., and Curry, D. (2000). Addressing key features of gang membership: Measuring the involvement of young members. Journal of Criminal Justice, 28, $473-482$.

Doherty, T. (1984). Creating a national cinema: The South Korean experience. Asian Survey, 24(8), 840-851.

Dukes, R., Martinez, R., and Stein, J. (1997). Precursors and consequences of membership in youth gangs. Crime and Delinquency, 56 (1), 3-34.

Emerson, Robert M., Rachel I. Fretz., and Linda Shaw. 1995. Writing Ethnographic Fieldnotes. Chicago: University of Chicago press.

Esbensen, F., Winfree, L., He, N., and Taylor,T. (2001). Youth gangs and definitional issues: when is a gang a gang, and why does it matter? Crime and Delinquency, 47(1), 105-130.

Finckenauer, J. and Chin, K. (2006). Asian transnational organized crime and its impact on the United States. Trends in Organized Crime, 10(2), 18-107.

Fong, H., and Yee, T.S. (2009). Overheard [Motion Picture]. Hong Kong: Bona Entertainment.

Fox, K., Lane., J., and Akers, R. (2010). Do perceptions of neighborhood disorganization predict crime or victimization? An examination of gang member versus non-gang member jail inmates. Journal of Criminal Justice

Fukasaku, K. (Director). (1972). Street Mobster [Motion Picture]. Japan: Toei Company.

Greene, J. and Pranis, K. (2007). Gang wars: The failure of enforcement tactics and the need for effective public safety strategies. Justice Policy Institute, 1-14.

Hagedorn, J. (1998). People and Folks: Gangs, Crime, and The Underclass in a Rustbelt City. Chicago: Lakeview Press.

Hagedorn, J. (2007). Gangs, institutions, race, and space: The Chicago School revisited. Pp 13-33 in Gangs in the Global City: Alternatives to Traditional Criminology. Edited by J. Hagedorn. Urbana, IL: University of Illinois Press.

Hagedorn, J. (2008). A World of Gangs: Armed Young Men and Gangsta Culture. Minneapolis, MN: University of Minnesota Press.

Hagedorn, J. (2009). A genealogy of gangs in Chicago: Bringing the State back into gang research. Global Gangs Conference. Retrieved from http://gangresearch.net/Archives/hagedorn/articles/genealog y.pdf

Hahm, H., Lahiff, M., and Guterman, N. (2003). Acculturation and parental attachment in Asian-American adolescents' alcohol use. The Journal of Adolescent Health, 33(2), 119-129.

Hendershot, C., MacPherson, L., Myers, M., Carr, L., and Wall, T. (2005). Psychosocial, cultural and genetic influences on alcohol use in Asian-American youth. Journal of Studies on Alcohol, 66(2), 185-195.

Hill, K., Howell, J., Hawkins, J., and Battin-Pearson, S. (1999). Childhood risk factors for adolescent gang membership: Results from the Seattle social development project. Journal of Research in Crime and Delinquency, 36(3), 300-322.

Hong, J. S. (2010). Understanding Vietnamese youth gangs in America: An ecological systems analysis. Aggression and Violent Behaviour, 15, 253-260.

Hong, J., Huang, H., and Kim, J. (2011). Substance abuse among Asian youth: An ecological review of the literature. Children and Youth Services Review, 33(5), 669-677. 
Howell, J. (2007). Menacing or mimicking? Realities of youth gangs. Juvenile and Family Court Journal, 58(2), 39-50.

Howell, J., and Egley, A. (2005). Moving risk factors into developmental theories of gang membership. Youth Violence and Juvenile Justice, 3(4), 334-354.

Huang, H. (2006). Dragon brothers and tiger sisters: A conceptual typology of counter-cultural actors and activities of American Chinatowns, China, Hong Kong, and Taiwan, 1912 - 1914. Crime, Law, and Social Change, 45, $71-91$.

Huang, H. (2007). From the Asian Boyz to the Zhu Lian Bang (the Bamboo Union Gang): A typological analysis of delinquent Asian gangs. Asian Criminology, 2, $127-143$.

Hughes, D.M., Chon K.Y., and Ellerman D.P. (2007). Modern-day comfort women: The U.S. military, transnational crime, and the trafficking of women. Violence Against Women, 13(9), 901-922.

Im, H. (2008). Pushed to the edge: Asian-American youth at risk. Korean Churches for Community Development, 1-32.

Jankowski, M.S. (1991). Island in the Street: Gangs and American Urban Society. Berkeley: University of California Press.

Joe, K. (1994). The new criminal conspiracy? Asian gangs and organized crime in San Francisco. Journal of Research in Crime and Delinquency, 31(4), 390-415.

Judith, A., and Steward, D. (2000). Social influences as explanations for substance use differences among Asian-American and European-American adolescents. Journal of Psychoactive Drugs, 32(1), 15-23.

Kang, L.H.I. (1993). The desiring of Asian female bodies: Interracial romance and cinematic subjection." Visual Anthropology Review, 9(1), 5-21.

Kelly, R., Chin K. and Fagan J. (1993). The activity, structure, and control of Chinese gangs: Law enforcement perspectives. Journal of Contemporary Criminal Justice, 9(3), 221-39.

Kent, D., and Felkenes, G. (1998). Cultural explanation for Vietnamese youth involvement in street gangs. Gangs and Delinquency Research, Westminster, CA: Westminster Police Department, Office of Research and Planning.

Kim, B., Atkinson, D., and Yang, P. (1999). The Asian values scale: Development, factor analysis, validation, and reliability. Journal of Counseling Psychology, 46(3), 342-352.

Kim, I., and Zane, N. (2002). Protective factors against substance use among Asian-American youth: A test of peer cluster theory. Journal of Community Psychology, 30(5), 565-584.

Kim, M.H., and Lee, K.S. (1999). Attack in the Gas Station [Motion Picture]. South Korea : Fun and Happiness.

Kim, N. Y. (2006). Patriarchy is so third world': Korean immigrant women and 'migrating' white Western masculinity. Social Problems, 53(4), 519-536.

Kim, S.K. (2006). Renaissance of Korean National Cinema as a terrain of negotiation and contention between the global and the local: Analyzing two Korean Blockbusters, Shiri (1999) and JSA (2000). The Essex Graduate Journal, 6, 1-15.

Lankin, P. and Shon, P. (forthcoming). Triad, Yakuza, and Jok-Pok: Asian Gangsters in Cinema. Handbook of Asian Criminology

Lasley, R. (1992). Age, social context, and street gang membership: Are youth gangs becoming adult gangs? Youth and Society, 23(4), 434-451.

Lau, W.K. (Producer), and Lau, W.K. and Mak, A. (Directors). (2002). Infernal Affairs [Motion Picture]. Hong Kong: Media Asia Distribution.

Law, D. and To J. (Producers), and To, J. (Director). (2005). Election [Motion Picture]. Hong Kong: China Star Entertainment Group.

Lee, C.S. (1980). South Korea 1979: Confrontation, assassination, and transition. Asian Survey, 20(1), 63-76.
Lee, T., Goebert, D., and Wallen, J. (2009). Acculturation factors and substance use among Asian American youth. Journal of Primary Prevention, 30(3-4), 453-473.

Lo, T. W. (2010). Beyond social capital: Triad organized crime in Hong Kong and China. British Journal of Criminology 50(5), 851-872.

Lo, T.W. (2012). Triadization of youth gangs in Hong Kong. British Journal of Criminology, 52 (3), 556-576.

Lu, S.H. (1997). Transnational Chinese Cinemas. Honolulu: University of Hawaii Press.

Maclean, B. and Milovanovic, D. (1997). Thinking critically about criminology. Pp. 11-16 in Thinking Critically About Crime. Edited by B. MacLean and D. Milovanovic. Richmond, BC: Collective Press.

Maruna, S. (2001). Making Good: How Ex-Convicts Reform and Rebuild Their Lives. Washington D.C.: American Psychological Association.

Meehan, A.J. (2000). The Organizational Career of Gang Statistics: The Politics of Policing Gangs. The Sociological Quarterly, 41(3):337-370.

Mercado, M. (2000). The invisible family: Counseling Asian American substance abusers and their families. The Family Journal, 8(3), 267-272.

Moore, J. (2007). Female gangs: gender and globalization. Pp 187203 in Gangs in the Global City: Alternatives to Traditional Criminology. Edited by J. Hagedorn. Urbana, IL: University of Illinois Press.

Mori, M., Nabeshima T. and Yoshida T. (Producers), and Kitano, T. (Director). (2003). Sonatine [Motion Picture]. Japan: Shouchiku Company.

Mosher, C., Rotolo, T., Krupski, A., and Stark, K. (2004). Minority adolescents and substance use risk/protective factors: A focus on inhalant use. Adolescence, 39 (155), 489-502.

Mouttapa, M., Watson, D., McCuller, W., Sussman, S., Weiss, J., Reiber, C., Lewis, D., and Tsai, W. (2010). I'm mad and I'm bad: Links between self-identification as a gangster, symptoms of anger, and alcohol use among minority juvenile offenders. Youth Violence and Juvenile Justice, 8(1), 71-82.

Naitô, S. (Producer), and Miike, T. (Director). (2003). Yakuza Demon [Motion Picture]. Japan Shochiku Eiga.

Ngai, N., Cheung, C., and Ngai, S. (2007). Cognitive and social influences on gang involvement among delinquents in three Chinese cities. Criminal Justice Periodicals, 42, $381-403$.

Pang, L. (2002). Masculinity in crisis: films of Milkyway Image and post-1997 Hong Kong Cinema. Feminist Media Studies, 2(3), 325-340.

Park, J.H., Gabbadon N.G., and Chernin A. R. (2006). Naturalizing racial difference through comedy: Asian, Black, and White views on racial stereotypes in Rush Hour 2. Journal of Communication, 56, 157-177.

Pih, K., De La Rosa, M., Rugh, D., and Mao, K. (2008). Different strokes for different gangs? An analysis of capital among Latino and Asian gang members. Pacific Sociological Association, 51(3), 473 - 494.

Pih, K., Hirose, A., and Mao, K. (2010). Gangs as contractors: the social organization of American Taiwanese youth gangs in Southern California. Trends in Organized Crime, 13, 115133.

Quinney, Richard. 1977. Class, State, and Crime. New York: David McKay.

Reiman, Jeffrey. 2008. The Rich Get Richer and the Poor Get Prison. Allyn and Bacon.

Said, E. (1978). Orientalism. New York: Vintage Books.

Sassen, S. (2007). The global city: one setting for new types of gang work and political culture? Pp 97-119 in Gangs in the Global City: Alternatives to Traditional Criminology. Edited by J. Hagedorn. Urbana, IL: University of Illinois Press. 
Schilling, M. (2003). The Yakuza Movie Book: A Guide to Japanese Gangster Films. Berkeley, CA: Stone Bridge Press.

Schwartz, S., Weisskirch, R., Zamboanga, B., Castillo, A., Ham, L., Hugnh, Q., Park, I., Donovan, R., Kim, S., and Vernon, M. (2011). Dimensions of acculturation: Associations with health risk behaviors among college students from immigrant families. Journal of Counseling Psychology, 58(1), 27-41.

Seok, M.H. (Producer), and Kwak, K.T. (Director). (2001). Friend [Motion Picture]. South Korea: Korea Pictures.

Shaw, C., and McKay, H. [1942] 1969. Juvenile Delinquency and Urban Areas. Chicago: University of Chicago Press.

Shek, Y.L. (2006). Asian American masculinity: A review of the literature. The Journal of Men's Studies, 14(3), 379-391.

Shim, D.B. (2006). Hybridity and the rise of Korean popular culture in Asia. Media, Culture and Society, 28(1), 25-44.

Shundo, K. and Yoshida T. (Producers), and Funkasaku, K. (Director). (1971). Sympathy for the Underdog [Motion Picture]. Japan: Toei Company

Strauss, Anselm. 1987. Qualitative Analysis for Social Scientists. Cambridge: Cambridge University Press.

Thai, N., Connell, C., and Kraemer, J. (2010). Substance use among Asian American adolescents: Influence of race, ethnicity, and acculturation in the context of key risk and protective factors. Asian American Journal of Psychology, 1(4), 261-274.

Thlang, A. (2010). Factors contributing to gang-related activities amongst Southeast Asian youth. Sacramento: California State University.

Tsunokai, G., and Kposowa, A. (2002). Asian gangs in the United States: The current state of the research literature. Crime, Law and Social Change, 37, $37-50$.

Tsunokai, G. (2005). Beyond the lenses of the 'model' minority myth: A descriptive portrait of Asian gang members. Journal of Gang Research, 12(4), 37 - 58.

Walker-Barnes, C.J. and Mason C.A. (2001). "Ethnic Difference in the Effect of Parenting on Gang Involvement and Gang Delinquency: A Longitudinal, Hierarchical Linear Modeling Perspective. Child Development, 72 (6), 1814-1831.

Wallace, J., and Bachman, J. (1991). Explaining racial/ethnic differences in adolescent drug use: The impact of background and lifestyle. Social Problems, 38(2), 333-357.
Wilson, K. (2007). Differential Association between Female Gangs and Male Gangs. (filebox.vt.edu/k/kgwilson/Female\%20gang\%20paper1.doc).

Winfree, L., Backstrom, T., and Mays, G., (1994). Social learning theory, self-reported delinquency, and youth gangs: A new twist on a general theory of crime and delinquency. Youth and Society, 26(2), 147-177.

Varano, S. P., Huebner, B. M., and Bynum, T. S. (2011). "Correlates and Consequences of Pre- Incarceration Gang Involvement among Incarcerated Youthful Felons". School of Justice Studies Faculty Papers. Paper 21.

Venkatesh, S. 2000. American Project: The Rise and Fall of a Modern Ghetto. London: Cambridge University Press.

Wacquant, L. (2007). Three pernicious premises in the study of the American ghetto. Pp 34-53 in Gangs in the Global City: Alternatives to Traditional Criminology. Edited by $\mathrm{J}$. Hagedorn. Urbana, IL: University of Illinois Press.

Yin, S. (2009). The dragon bites back; the movies may make triad life look glamorous, but young people who get drawn into the underworld find themselves in a dangerous and confusing place. South China Morning Post April 23.

Young, J. (1997). Left realism: The basics. Pp. 28-36 in Thinking Critically About Crime. Edited by B. MacLean and D. Milovanovic. Richmond, BC: Collective Press.

Young, J. (2007). Globalization and social exclusion: The sociology of vindictiveness and the criminology of transgression. Pp 54-93 in Gangs in the Global City: Alternatives to Traditional Criminology. Edited by J. Hagedorn. Urbana, IL: University of Illinois Press.

Zhang, S., and Chin., K. (2008). Snakeheads, mules, and protective umbrellas: A review of current research on Chinese organized crime. Crime, Law, and Social Change, 50, 177 195.

Zhang, S., and Chin., K. (2003). The declining significance of triad societies in transnational illegal activities: A structural deficiency perspective. British Journal of Criminology, 43(3), $469-488$.

\section{DOI: http://dx.doi.org/10.6000/1929-4409.2012.01.4}

(C) 2012 De Caires et al.; Licensee Lifescience Global.

This is an open access article licensed under the terms of the Creative Commons Attribution Non-Commercial License (http://creativecommons.org/licenses/by-nc/3.0/) which permits unrestricted, non-commercial use, distribution and reproduction in any medium, provided the work is properly cited. 